Wahana Didaktika Vol. 16 No.3 September 2018 : 298-307

\title{
UPAYA MENINGKATKAN HASIL BELAJAR PKN MELALUI MODEL PEMBELAJARAN KOOPERATIF TIPE THINK PAIR SHARE
}

\author{
Oleh: Hayatul Murni \\ (Guru SD Negeri 19 Palembang) \\ Email: hayatulmurni@gmail.com
}

\begin{abstract}
Abstrak
Penelitian tindakan kelas ini bertujuan untuk mengetahui apakah model pembelajaran kooperatif tipe Think Pair Share (TPS) dapat meningkatan hasil belajar PKn pada peserta didik kelas V.B SD Negeri 19 Palembang. Penelitian ini menggunakan metode Penelitian Tindakan Kelas (PTK) yang dilaksanakan selama 3 bulan bertempat di kelas V.B SD Negeri 19 Palembang. Sebagai subjek penelitian adalah peserta didik kelas $V . B$ sebanyak 22 orang dan sumber data diperoleh dari peserta didik, teman sejawat sebagai kolaborator, dan dokumen nilai. Sebagai alat pengumpulan data digunakan instrumen soal tes dan lembar observasi. Analisis data dilakukan dengan deskriptif kualitatif komperatif dengan mencermati ketuntasan belajar peserta didik, perolehan nilai, keberhasilan dan kegagalan dalam pelaksanaan pembelajaran serta kelancaran dan hambatan pembelajaran peserta didik. Sebagai indikator kinerja, diharapkan tercapainya ketuntasan belajar peserta didik 85\%. Penelitian Tindakan Kelas ini menggunakan prosedur: perencanaan, pelaksanaan, observasi, dan refleksi. Hasil penelitian menunjukkan meningkatnya hasil belajar peserta didik pada pra siklus (45.16\%), siklus I (70.97\%), dan siklus II (87.10\%). Dengan demikian sebagian besar peserta didik kelas V.B SD Negeri 19 Palembang mengalami peningkatan hasil belajar.
\end{abstract}

Kata Kunci: PKn, Model Pembelajaran Kooperatif Tipe Think Pair Share

\section{EFFORTS TO IMPROVE PKN LEARNING OUTCOMES THROUGH TYPE THINK PAIR SHARE COOPERATIVE LEARNING MODEL}

\begin{abstract}
Class action research aims to find out whether cooperative learning model Think Pair Share can improve learning outcomes among students grade civics V.B SD Negeri 19 Palembang. This study uses a class action research (CAR), which was conducted over three months housed in class V.B SD Negeri 19 Palembang. As research subjects are students class V.B many as 22 people and data resources obtained from students, colleagues as collaborators, and documents of value. As a data collection tool used instrument of test and observation sheet. The use of engineering test data using the study of students and recording observations. Data was analyzed using descriptive qualitative comparative with examining the completeness of learners, the acquisition value, success and failure in the implementation of learning as well as the smooth and barriers to education of students. As an indicator of performance, is expected to achieve mastery of learners $85 \%$. This class action research using the procedure: planning, implementation, observation, and reflection. Results showed increasing learning outcomes of students in pre cycle (45.16\%), the first cycle (70.97\%), and the second cycle (87.10\%). Thus the majority of learners class V.B SD Negeri 19 Palembang increased learning outcomes.
\end{abstract}

Keywords: Civics, Model Cooperative Learning Think Pair Share. 
Upaya Meningkatkan Hasil Belajar...(Hayatul Murni)

\section{A. PENDAhuluan}

Pendidikan adalah suatu proses dalam rangka mempengaruhi peserta didik agar dapat menyesuaikan diri sebaik mungkin terhadap lingkungannya dan dengan demikian akan menimbulkan perubahan dalam dirinya yang memungkinkan untuk berfungsi dalam kehidupan bermasyarakat (Hamalik, 2010:3). Pendidikan ialah proses dimana seseorang mengembangkan kemampuan sikap dan bentuk-bentuk tingkah laku lainnya di dalam masyarakat dimana ia hidup, proses sosial dimana orang dihadapkan pada pengaruh lingkungan yang terpilih dan terkontrol (khususnya yang datang dari sekolah), sehingga ia dapat memperoleh atau mengalami perkembangan kemampuan sosial dan kemampuan individu yang optimum. Kemajuan dan kemunduran suatu bangsa tidak terlepas dari faktor pendidikan, karena pendidikan mempunyai peranan penting dalam usaha meningkatkan kualitas sumber daya manusia yang merupakan salah satu unsur terpenting dalam mewujudkan dan menyempurnakan mutu pendidikan dengan meningkatkan kualitas proses belajar mengajar. Oleh karena itu, keberhasilan di dalam dunia pendidikan banyak tertempuh kepada cara proses mengajar yang dilakukan oleh seorang guru.

Dalam proses pembelajaran, berbagai macam strategi, metode dan pendekatan pembelajaran pada dasarnya diciptakan adalah untuk memajukan dunia pendidikan kita khususnya di Indonesia dan untuk menjadikan pembelajaran tersebut bermakna serta mempunyai arti penting tidak hanya pendidikan formal tetapi juga dapat diaplikasikan di kehidupan sehari-hari, agar informasi atau pelajaran yang dapat menjadi bermakna.

Berdasarkan pengalaman penulis selama menjadi guru kelas V.B SD Negeri 19 Palembang, masih banyak nilai peserta didik di bawah kriteria ketuntasan minimum (KKM). Hal ini disebabkan oleh beberapa kendala dalam proses pembelajaran. Umumnya guru masih menggunakan pembelajaran konvensional, dimana dalam proses belajar peserta didik bertindak sebagai penerima saja dan guru sebagai penyalur segala bentuk informasi, sehingga dalam proses pembelajaran peserta didik tergolong kurang aktif, kedua peserta didik kurang optimal dalam mengikuti pembelajaran sehingga pemahaman konsep peserta didik 
kurang baik dan ketika peserta didik menganggap pembelajaran PKn sebagai hal yang sulit untuk dipelajari sehingga dalam proses pembelajaran peserta didik kurang antusias, kurangnya dorongan terhadap peserta didik untuk mengembangkan kemampuan berpikir yang menyebabkan masih rendahnya daya serap peserta didik.

Model pembelajaran yang dapat digunakan guru hendaknya dapat menghasilkan hasil belajar peserta didik yang lebih baik di antaranya adalah model pembelajaran kooperatif tipe Think Pair Share dalam pembelajaran PKn. Think Pair Share termasuk dalam model pembelajaran kooperatif yang dapat meningkatkan rasa percaya diri dan keaktifan peserta didik dalam belajar hal ini dikarenakan setiap kelompok terdiri dari dua orang sehingga setiap peserta didik akan mendapatkan kesempatan untuk berpartisipasi dalam kelas.

Untuk mengetahui apakah dengan menggunakan model pembelajaran kooperatif tipe think pair share hasil belajar PKn dapat meningkat maka penulis tertarik untuk melakukan penelitian yang berjudul; "Upaya Meningkatakan Hasil Belajar PKn melalui Model Pembelajaran Kooperatif Tipe Think Pair Share (TPS) pada Peserta Didik Kelas V.B SD Negeri 19 Palembang".

Berdasarkan latar belakang yang dikemukakan di atas, maka yang menjadi permasalahan dalam penelitian ini adalah; apakah model pembelajaran kooperatif tipe Think Pair Share (TPS) dapat meningkatan hasil belajar PKn pada peserta didik kelas V.B SD Negeri 19 Palembang. Sesuai dengan permasalahan di atas, maka tujuan dari penelitian ini adalah untuk mengetahui apakah model pembelajaran kooperatif tipe Think Pair Share (TPS) dapat meningkatan hasil belajar PKn pada peserta didik kelas V.B SD Negeri 19 Palembang.

Penelitian ini diharapkan dapat memberi manfaat :

1. Bagi peserta didik, dapat memberikan motivasi belajar PKn sehingga peserta didik dapat lebih aktif belajar dan dapat meningkatkan hasil belajar peserta didik menggunakan model pembelajaran kooperatif tipe Think Pair Share (TPS).

2. Bagi guru, hendaknya pembelajaran dengan menggunakan model pembelajaran kooperatif tipe Think Pair Share (TPS) dapat dijadikan salah 
Upaya Meningkatkan Hasil Belajar...(Hayatul Murni)

satu alternative belajar PKn

3. Bagi kepala sekolah, sebagai masukan untuk dapat menerapkan model pembelajaran kooperatif tipe Think Pair Share (TPS) dalam proses pembelajaran dan dalam menentukan langkah-langkah pembelajaran yang lebih baik.

4. Bagi peneliti lain, sebagai pengalaman dan pelajaran bagi penulis dalam menerapkan pembelajaran pada mata pelajaran matematika dengan menggunakan model pembelajaran kooperatif tipe Think Pair Share (TPS).

Belajar merupakan suatu hal yang sangat penting bagi seseorang, karena belajar merupakan usaha sadar dalam proses pembelajaran yang terjadi di dalam diri seseorang, menurut Hamalik (2003:40) mengatakan bahwa "belajar adalah suatu proses perubahan pada tingkah laku manusia dengan adanya interaksi maupun lingkungan alam sekitar”.

Hasil belajar merupakan proses untuk menentukan nilai belajar peserta didik melalui kegiatan penilaian dan/atau pengukuran hasil belajar. Berdasarkan pengertian evaluasi hasil belajar kita dapat menengarai tujuan utamanya adalah untuk mengetahui tingkat keberhasilan yang dicapai oleh peserta didik setelah mengikuti suatu kegiatan pembelajaran, dimana tingkat keberhasilan tersebut kemudian ditandai dengan skala nilai berupa huruf atau angka atau symbol (Dimyati dan Mudjiono, 2009:200).

Pendidikan Kewarganegaraan merupakan salah satu mata pelajaran yang dapat membentuk diri yang beragam dari segi agama, sosio-kultural, bahasa, usia, untuk menjadi warga negara yang cerdas, terampil dan berkarakter yang dilandasi oleh UUD 1945 (Sudjana, 2003:4). Pendidikan Kewarganegaraan adalah mata pelajaran yang secara umum bertujuan untuk mengembangkan potensi individu warga negara Indonesia, sehingga memiliki wawasan, sikap, dan keterampilan kewarganegaraan yang memadai dan memungkinkan untuk berpartisipasi secara cerdas dan bertanggung jawab dalam berbagai kehidupan bermasyarakat, berbangsa dan bernegara (Sudjatmiko, 2008:12).

Berdasarkan pendapat di atas jelas bagi kita bahwa PKn bertujuan mengembangkan potensi individu warga negara, dengan demikian maka seorang 
guru PKn haruslah menjadi guru yang berkualitas dan profesional, sebab jika guru tidak berkualitas tentu tujuan PKn itu sendiri tidak tercapai. Model pembelajaran menurut Smaldino (Pribadi, 2009:42) merupakan proses atau prosedur yang digunakan oleh guru atau instruktur untuk mencapai tujuan atau kompetensi. Pemilihan model pembelajaran perlu didasarkan pada kesesuaian dengan tugas dan tujuan pembelajaran yang ditempuh peserta didik. Pemilihan model yang tepat akan membantu peserta didik dalam mencapai tujuan pembelajaran yang telah ditetapkan.

Belajar kooperatif bukanlah sesuatau yang baru. Dalam belajar kooperatif, peserta didik dibentuk dalam kelompok-kelompok yang terdiri dari 4 atau 5 orang untuk bekerjasama dalam menguasai materi yang diberikan guru (Slavin, 1995; Eggen \& Kauchak, dalam Trianto, 2011:56).

Artzt dan Newman (1990:448) menyatakan bahwa dalam belajar kooperatif peserta didik belajar bersama dalam suatu tim dalam menyelasaikan tugas - tugas kelompok untuk mencapai tujuan bersama. Jadi setiap anggota kelompok memiliki tangguang jawab yang sama untuk keberhasilan kelompoknya (Trianto, 2011:56). Model pembelajaran kooperatif adalah kegiatan pembelajaran dengan cara berkelompok untuk bekerja sama saling membantu mengkonstruksi konsep, menyelesaikan persoalan, atau inkuiri (Suyatno, 2009:51).

Dari beberapa pernyataan di atas dapat disimpulkan bahawa pembelajaran kooperatif merupakan suatu proses pembelajaran yang dilakukan secara berkelopmpok agar peserta didik dapat memahami konsep dan dapat menyelesaikan persoalan serta dapat berkerja secara bersama-sama untuk mencapai tujuan pembelajaran. Think-Pair-Share pertama kali dikembangkan oleh Frang Lyman dan koleganya di Universitas Maryland (dalam Arends 1997:74), menyatakan bahwa Thiks-Pair-Share merupakan suatu cara yang efektif untuk membuat variasi suasana diskusi kelas. Dengan asumsi bahwa semua resitasi atau diskusi membutuhkan pengaturan untuk mengendalikan kelas secara keseluruhan, dan prosedur yang digunakan dalam Think-Pair-Share dapat memberi peserta didik lebih banyak waktu berpikir, untuk merespons dan saling membantu. Guru memperkirakan hanya melengkapi penyajian singkat atau 
Upaya Meningkatkan Hasil Belajar...(Hayatul Murni)

peserta didik membaca tugas, atau situasi yang menjadi tanda tanya. Sekarang guru menginginkan peserta didik mempertimbangkan lebih banyak apa yang telah dijelaskan dan dialami. Guru memilih menggunakan think-pair-share untuk membandingkan tanya jawab kelompok keseluruhan (Trianto, 2011:132-133).

\section{B. METODOLOGI PENELITIAN}

Penelitian ini termasuk dalam jenis penelitian tindakan kelas (PTK). Ciri utama dari penelitian tindakan kelas yakni adanya tindakan-tindakan tertentu untuk memperbaiki dan menyempurnakan proses pembelajaran di kelas. Penelitian tindakan kelas yang digunakan adalah penelitian partisipan dimana peneliti terlibat secara langsung dan penuh dalam penelitian mulai dari awal sampai akhir penelitian. Penelitian ini dilaksanakan di SD Negeri 19 Palembang, dipilihnya sekolah ini sebagai tempat meneliti karena peneliti adalah sebagai guru kelas di SD tersebut.

Adapun waktu penelitian ini dilaksanakan pada bulan Agustus sampai dengan bulan Oktober tahun pelajaran 2015/2016, karena pada tahun pelajaran ini peneliti guru kelas di SD Negeri 19 Palembang, pokok bahasan yang disampaikan adalah "meneladani nilai-nilai juang para tokoh yang berperan dalam proses perumusan Pancasila sebagai Dasar Negara dalam kehidupan sehari-hari”. Subjek yang dimaksud tindakan dalam penelitian ini adalah peserta didik kelas V.B SD Negeri 19 Palembang yang berjumlah 31 peserta didik. Mereka merupakan peserta didik kelas V.B semester I tahun pelajaran 2015/2016, sedangkan partisipan yang terlibat dalam penelitian ini adalah guru kelas dan teman sejawat lainnya.

Indikator keberhasilan penelitian ini dengan menggunakan hasil nilai pembelajaran patokan KKM 85\% dan telah terjadinya peningkatan hasil belajar peserta didik terhadap pelajaran PKn. Model penelitian tindakan kelas ini merujuk pada model Kemmis dan MC Taggart yang menguraikan bahwa tindakan yang digambarkan sebagai suatu proses yang dinamis dari aspek perencanaan, tindakan (pelaksanaan), observasi (pengamatan), refleksi. Pengumpulan data dalam penelitian ini dilakukan dengan menggunakan teknik catatan lapangan, lembar kerja peserta didik, tes tertulis, dan dokumen. 


\section{HASIL PENELITIAN DAN PEMBAHASAN}

Tabel 1. Rekapitulasi Hasil Tes Pra Siklus

\begin{tabular}{|c|l|c|}
\hline No. & \multicolumn{1}{|c|}{ Uraian } & Pra Siklus \\
\hline \hline 1 & Nilai rata-rata tes & 69.77 \\
\hline 2 & Jumlah peserta didik yang tuntas belajar & 14 \\
\hline 3 & Jumlah peserta didik yang tidak tuntas belajar & 17 \\
\hline 4 & Persentase ketuntasan belajar & 45.16 \\
\hline 5 & Persentase tidak tuntas belajar & 54.84 \\
\hline
\end{tabular}

Berdasarkan tabel 1 di atas dapat diketahui bahwa peserta didik yang nilainya mencapai kriteria ketuntasan minimal yang sudah ditetapkan yaitu 75 , sebagai berikut: peserta didik yang mendapatkan nilai di atas/sama dengan 75 hanya berjumlah 14 orang dengan persentase 45.16\%. Peserta didik yang mendapatkan nilai kurang dari 75 berjumlah 17 orang dengan persentase $54.84 \%$. Angka ini masih jauh dari indikator keberhasilan yang diharapkan yaitu $85 \%$ peserta didik yang memperoleh nilai di atas 75 .

Tabel 2. Rekapitulasi Rata-Rata Hasil Tes Pada Siklus I

\begin{tabular}{|c|l|c|}
\hline No. & \multicolumn{1}{|c|}{ Uraian } & Siklus I \\
\hline 1 & Nilai rata-rata tes & 74.61 \\
\hline 2 & Jumlah peserta didik yang tuntas belajar & 22 \\
\hline 3 & Jumlah peserta didik yang tidak tuntas belajar & 9 \\
\hline 4 & Persentase ketuntasan belajar & 70.97 \\
\hline 5 & Persentase tidak tuntas belajar & 29.03 \\
\hline
\end{tabular}

Berdasarkan tabel 2 di atas dapat dijelaskan bahwa dengan menerapkan pembelajaran dengan menggunakan model pembelajaran kooperatif tipe Think Pair Share (TPS) diperoleh ketuntasan belajar peserta didik pada pertemuan pertama peserta didik yang tuntas belajar hanya 19 orang dan yang tidak tuntas 12 orang. Sedangkan pada pertemuan kedua peserta didik yang tuntas belajar hanya 24, dan yang tidak tuntas 7 orang, jadi dapat disimpulkan rata-rata ketuntasan belajar peserta didik pada siklus I yang tuntas belajar 22 orang dan persentase $70.97 \%$, dan yang belum tuntas 9 arang dengan persentase $29,03 \%$. Hasil tersebut menunjukkan bahwa pada siklus pertama secara klasikal peserta didik belum 
tuntas belajar, karena peserta didik yang memperoleh nilai $\geq 75$ hanya sebesar $70.97 \%$ lebih kecil dari persentase ketuntasan yang dikehendaki yaitu sebesar $85 \%$.

Tabel 3. Rekapitulasi Rata-Rata Hasil Tes Pada Siklus II

\begin{tabular}{|c|l|c|}
\hline No. & \multicolumn{1}{|c|}{ Uraian } & Siklus II \\
\hline \hline 1 & Nilai rata-rata tes & 80.69 \\
\hline 2 & Jumlah peserta didik yang tuntas belajar & 27 \\
\hline 3 & Jumlah peserta didik yang tidak tuntas belajar & 4 \\
\hline 4 & Persentase ketuntasan belajar & 87.10 \\
\hline 5 & Persentase tidak tuntas belajar & 12.90 \\
\hline
\end{tabular}

Berdasarkan tabel 3 di atas dapat dijelaskan bahwa dengan menerapkan pembelajaran dengan menggunakan model pembelajaran kooperatif tipe Think Pair Share (TPS) diperoleh ketuntasan belajar peserta didik pada pertemuan pertama peserta didik yang tuntas belajar hanya 25 orang dan yang tidak tuntas 6 orang. Sedangkan pada pertemuan kedua peserta didik yang tuntas belajar hanya 29, dan yang tidak tuntas 2 orang, jadi dapat disimpulkan rata-rata ketuntasan belajar peserta didik pada siklus I yang tuntas belajar 27 orang dan persentase $87.10 \%$, dan yang belum tuntas 4 arang dengan persentase $12,90 \%$. Maka secara klasikal ketuntasan belajar yang telah tercapai sebesar $87.10 \%$ (termasuk kategori tuntas). Hasil pada siklus II ini mengalami peningkatan lebih baik dari siklus I. Adanya peningkatan hasil belajar pada siklus II ini dipengaruhi oleh adanya peningkatan kemampuan peserta didik dalam mempelajari materi pelajaran yang telah diterapkan selama ini.

Berdasarkan hasil penelitian ini menunjukkan bahwa pembelajaran dengan menggunakan model pembelajaran kooperatif tipe Think Pair Share (TPS) memiliki dampak positif dalam meningkatkan prestasi belajar peserta didik. Hal ini dapat dilihat dari semakin mantapnya pemahaman dan penguasaan peserta didik terhadap materi yang telah disampaikan guru selama ini ketuntasan belajar meningkat dari sebelum tindakan dan sesudah tindakan, yaitu; pra siklus (45.16\%), siklus I (70.97\%), dan siklus II (87.10\%). Pada siklus II ketuntasan belajar peserta didik secara klasikal telah tercapai dan mengalami peningkatan yang sangat baik. 


\section{KESIMPULAN}

Berdasarkan hasil penelitian yang telah dikemukakan pada bab sebelumnya, maka kesimpulan yang dapat diambil dalam penelitian ini adalah sebagai berikut: Pembelajaran kooperatif tipe Think Pair Share (TPS) memiliki dampak positif dalam meningkatkan hasil belajar peserta didik yang ditandai dengan peningkatan ketuntasan belajar peserta didik dalam setiap siklus, yaitu pra siklus (45.16\%), siklus I (70.97\%), dan siklus II (87.10\%). Penerapan pembelajaran kooperatif tipe Think Pair Share (TPS) mempunyai pengaruh positif, yaitu dapat meningkatkan motivasi belajar peserta didik yang ditunjukan dengan hasil observasi yang guru pengamat lihat, dan peserta didik tertarik terhadap model pembelajaran kooperatif tipe Think Pair Share (TPS) sehingga mereka menjadi termotivasi untuk belajar.

Dari hasil penelitian yang diperoleh dari uraian sebelumnya agar proses belajar mengajar PKn lebih efektif dan lebih memberikan hasil yang optimal bagi peserta didik, maka disampaikan saran sebagai berikut: untuk melaksanakan pembelajaran memerlukan persiapan yang cukup matang, sehingga guru harus mampu menentukan atau memilih topik yang benar-benar bisa diterapkan dengan pembelajaran PKn dalam proses belajar mengajar sehingga diperoleh hasil yang optimal. Dalam rangka meningkatkan hasil belajar peserta didik, guru hendaknya lebih sering melatih peserta didik dengan berbagai model pembelajaran, walau dalam taraf yang sederhana, dimana peserta didik nantinya dapat menemukan pengetahuan baru, memperoleh konsep dan keterampilan, sehingga peserta didik berhasil atau mampu memecahkan masalah-masalah yang dihadapinya. Perlu adanya penelitian yang lebih lanjut, karena hasil penelitian ini hanya dilakukan di SD Negeri 19 Palembang. 
Upaya Meningkatkan Hasil Belajar...(Hayatul Murni)

\section{DAFTAR PUSTAKA}

Arends, R. (1997). Classroom Instructional and Management. New York: McGraw Hill Comapanies.

Artzt, A. dan Newman, C. (1990), How to Use Cooperative Learning in the Mathematics Class, Reston, VA: National Council of Teachers of Mathematics.

Dimyati dan Mudjiono. (2009). Belajar dan Pembelajaran. Jakarta: Rineka Cipta.

Hamalik, O. (2003). Perencanaan Pengajaran Berdasarkan Pendekatan Sistem. Jakarta: Bumi Aksara.

Hamalik, O. (2010). Kurikulum dan Pembelajaran. Jakarta: Bumi Aksara

Pribadi, B. (2009). Model Desain Sistem Pembelajaran. Jakarta : PT. Dian Rakyat.

Sudjana. (2003). Teknik Analisis Regresi dan Korelasi. Bandung. Tarsito.

Sudjatmiko. (2018). Hakekat-Pendidikan Kewarganegaraan-Pkn.html. Diakses Februari 21 , 2012, dari httpwww.sekolahdasar.net

Suyatno. (2009). Menjelajah Pembelajaran Inovatif. Surabaya: Masmedia Buana Pustaka.

Trianto. (2011). Mendesain Model Pembelajaran Inovatif-Progresif. Jakarta: Kencana. 